\title{
Diurnal feeding strategies of the Ferruginous Duck (Aythya nyroca) in Lake Tonga (Northeastern Algeria)
}

\author{
Khalil DraId ${ }^{1 *}$, Badis BAKHOUCHE ${ }^{2}$, Naouel LAHLAH ${ }^{3}$, Imed \\ DJEMADI $^{4} \&$ Mourad Bensouilah ${ }^{5}$
}

Received: September 18, 2018 -Revised: December 13, 2018 -Accepted: December 15, 2018

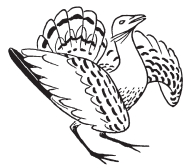

Draidi, K., Bakhouche, B., Lahlah, N., Djemadi, I. \& Bensouilah, M. 2019. Diurnal feeding strategies of the Ferruginous Duck (Aythya nyroca) in Lake Tonga (Northeastern Algeria). - Ornis Hungarica 27(1): 85-98. DOI: 10.2478/orhu-2019-0005 behaviour of ducks. We monitored the annual cycle of birds through two fieldtrips per month. The instantaneous behaviour of birds was recorded in regular 30-minute intervals from 7 a.m. to 4:30 p.m., amounting a total of 456 observation hours. Food searching activity corresponds to a quarter of the total diurnal time budget of the Ferruginous Duck. Foraging behaviour was classified into five categories dominated by the "diving", which is almost $45.61 \%$ of the total search time. Foraging activities at the water surface considered to be secondary activities, including feeding by "bill", "neck and head", and "beak and head" in a rate of $19.86 \%, 14.53 \%$, and $13.98 \%$, respectively. The "toggle" remains a minor activity and represents only $5.99 \%$ of foraging time. The feeding behaviour of this species correlated to several environmental parameters (rainfall, temperature and wind velocity), and linked to the group size of ducks visiting the lake. Regarding the food intensity, our results show the highest values for "bill and head" behaviour. "Diving" has the longest feeding interval (16.16 \pm 14.1 minutes), while foraging by "bill" has the shortest $(0.69 \pm 0.48$ minutes $)$.

Keywords: El-kala, foraging behaviour, near threatened species, energy budget, Anatidae, wildfowl

Összefoglalás Annak ellenére, hogy a cigányrécével (Aythya nyroca) számos tanulmány foglalkozott, táplálkozási szokásai kevésbé ismertek. Jelen tanulmányban a faj nappali táplálékszerzéssel kapcsolatos viselkedését vizsgáltuk. A madarak éves táplálkozási ciklusának monitorozása havonta két terepbejárással történt. Az adott viselkedési mintákat 30 perces időintervallumokban rögzítettük: reggel 7 óra 30 perctől délután 16 óra 30 percig, összesen 456 megfigyeléssel töltött órában. A táplálék keresésével töltött idő hozzávetőlegesen a réce napi aktivitásának negyedét teszi ki. A táplálékszerzéssel kapcsolatos viselkedési mintákat öt kategóriába soroltuk: „merülés” (kereséssel töltött idő 45,61\%-a), másodlagos táplálékszerzés a vízfelszínről, a „csőr a felszín alatt” (19,86\%), a „nyak és fej a felszín alatt” $(14,53 \%$, ),csőr és fej a felszín alatt” (13,98\%), valamint a „tótágast állva" történő táplálékszerzés, mely az idő 5,99\%-át teszi ki. E faj táplálkozási szokásai számos környezeti paraméterrel (csapadék, hőmérséklet és szélsebesség) függnek össze, és a tavat látogató récék csoportmérete is befolyásoló tényező. A táplálékforrás intenzitásának tekintetében a legmagasabb értékeket a „csőr és fej a felszín alatt” viselkedési mintára kaptuk. A „merülés” mutatta a leghosszabb időintervallumot $(16,16 \pm 14,1$ perc), míg a legrövidebbet $(0,69 \pm 0,48$ perc $)$ a "csőr a felszín alatt" viselkedési minta.

Kulcsszavak: El-kala, táplálékszerzés, mérsékelten fenyegetett fajok, energiaforgalom, Anatidae, vízimadarak

\author{
${ }^{1}$ Laboratory of Ecobiology of Aquatic and Littoral Environments, University of Badji Mokhtar Annaba, \\ 23000, Algeria \\ ${ }^{2}$ Laboratory of Dynamics and Biodiversity (USTHB), USTHB, FSB, Bp32 El Alia, Bab Ezzouar, \\ Algies, Algeria \\ ${ }^{3}$ Lake Forest College 555 N Sheridan Rd, Lake Forest, IL 60045, USA
}


${ }^{4}$ Laboratory Ecology of Terrestrial and Aquatic Systems, University of Badji Mokhtar Annaba,
23000, Algeria
${ }^{5}$ Laboratory of Ecobiology of aquatic and littoral environments University of Badji Mokhtar Annaba,
23000, Algeria
* corresponding author: khalildraidi@yahoo.fr

\section{Introduction}

Understanding foraging strategies that animals use when balancing energy budgets can lead to a clearer view of potential constraints to populations, as well as species' behavioral scope, when responding to environmental changes (Pyke 1984). The allocation of time into foraging varies among taxa and individuals and may have important implications for meeting energy requirements (Bautista et al. 1998). When facing with food or energetic deficits, the ability to adjust foraging time and strategies allows animals to maintain the necessary rate of energy gaining. For obligate diurnal foragers, day length forces strict limits on available foraging time. The Ferruginous Duck (Aythya nyroca) is a shy and cautious diving duck widely distributed in Asia, Africa, and Europe. During the wintering season, this species is a regular visitor in El-Kala wetlands. It is also reported as nesting species in North Africa since the beginning of the $20^{\text {th }}$ century. Its nesting was observed for the first time in 1972 in Algeria (François 1975). During the last decades, nesting populations in this region have suffered serious declines, as well as changes in their distribution (Ali \& Ripley 1978, Perennou et al. 1994, Callaghan 1997, Lopez \& Mundkur 1997, Grimmett et al. 1999, Robinson \& Hughes 2003).

According to the Red List of Threatened Species (IUCN 2015), the Ferruginous Duck occupies the 'near threatened' status. In Algeria, this species is protected by decrees N ${ }^{\circ} 83-509$ of $20^{\text {th }}$ August 1983 and $N^{\circ} 06-05$ of $15^{\text {th }}$ July 2006 , relating to the protection and preservation of some critically threatened species. A. nyroca has also been presented as a priority species in 4 prominent international conservation treaties: the European Union Bird Directive, the Bern Convention, the Bonn Convention, and the African Eurasian Migratory Waterbird Agreement (Robinson \& Hughes 2003).

The Ferruginous Duck is omnivorous. In Uzbekistan, stomach content analysis reveals $78 \%$ of sprouts and freshwater plant seeds and $22 \%$ of aquatic insects during the nesting period (Kashkarov \& Mukhina 1997). In Bulgaria, this duck feeds mostly on seeds and other aquatic plants such as pondweeds (Potamogeton spp.), sedges (Carex spp.), hornworts (Ceratophyllum spp.) and bulrushes (Scirpus spp.) (Ayaichia et al. 2017). However, animal material can dominate locally or temporarily and includes invertebrates such as chironomids (Chironomidae), snails (gastropods), coleopteran beetles and also small fish and frogs (Phillips 1923, Dementiev \& Gladkov 1952, Sterbetz 1967, Cramp \& Simmons 1977, Amat \& Soriguer 1982, Paspaleva et al. 1984, Patrikeev 1996, Green 1998). In addition to the measurement of the total time spent in foraging, which has been rather widely discussed in several studies (Green 1998, Ayaichia et al. 2017), understanding feeding methods used by ducks may also enquire on constraints beared by populations. We already know that feeding only with submerged bill may be linked to the choice of feeding in shallower zones, but could also be a response to a need of maintaining activity that requires alertness (remaining eyes 
above the surface) where predation risks and disturbance are the highest (Guillemain et al. 2002). Moreover, the increasing of foraging depth during winter reflects a gradual depletion of resources (Guillemain \& Fritz 2002), even a change in consumed prey types (Guillemain et al. 2000). In birds, foraging is a limiting process which allows energetic gain. A good wintering season in foraging terms would permit the reconstitution of endogen reserves mobilised during migration and/or to finish moulting (Heitmeyer 1988). Foraging also influences breeding, which is a costly phenomenon on nutritive elements, and can require not only the lepidic reserves but either the stocked tissue proteins (Heitmeyer 1988, Owen \& Black 1990). In Anatidae, species often reproduce early, the clutch size and the date of laying depend on the cumulated reserves before arrival on the nesting sites (Ankney \& MacInnes 1978, Pattenden \& Boga 1989). During the migration journey to the wintering sites, birds forage intensively to reconstitute energetic reserves (Landys et al. 2004). Foraging behaviour is determined by foraging niche and depends generally on certain factors of climatic zones and charging capacity (Ankney \& MacInnes 1978, Krapu 1981, Drobney 1982, Pattenden \& Boag 1989).

In this study, we tried to understand why Ferruginous Duck changes its foraging methods. First, we searched factors, which affect the processes via feeding behaviour. We examined the relation between feeding methods and some environmental factors (temperature, rainfalls, and wind speed). We also considered the relationship between the choice of a foraging method and the ducks' group sizes present at the Lake Tonga (influence of the competition).

\section{Materials and Methods}

Field work was conducted over an annual cycle, from January to December in 2013 with two surveys per month. Two classical methods were implemented: The Scan Sampling and Focal Individual Sampling. Scan sampling requires that the behaviour of individuals in the sample is being recorded instantaneously (Altmann 1974). Many waterfowl activity budget studies, utilizing scan sampling, involve surveying the entire local population at the time of sampling, i.e. all birds on a pond (Skead 1977, Norman et al. 1979, O'Donoghue \& O'Halloran 1994, Adair et al. 1996). In some instances, the study site is too large to be sampled from one point (Campbell 1978). A solution to this problem is to divide the site into non-overlapping sections that are observed separately. Then, data needs to be weighted according to the number of birds observed in the different sections (Hepworth \& Hamilton 2001). In our case, it took approximately $1 \mathrm{~h}$ to sample the entire pond. The different behaviours of the monitored ducks were identified using binoculars, scanning from left to right (Hepworth \& Hamilton 2001). To facilitate the sampling, the pond was divided into 5 sections. Antagonistic behaviour was excluded because of its infrequency. All of the different types of feeding behaviour by submersion of the beak, the head, the beak and head, the head and neck or by diving were considered as feeding activities. The aim of this sampling was to estimate the number of individuals in each activity category, on each sampling occasion. These numbers would then be used to estimate the proportion (or percentage) of individuals in each category. Focal observations (10 mins, Altmann 1974) were conducted 
on feeding individuals chosen at chance; each change in behaviour was recorded. Observations took place in the site twice monthly between 7 a.m. and 4:30 p.m., for a total of 24 study days. Thereby, a total of 456 scans were performed. Data was recorded by the same observers throughout the study. Presumed repetition of observations on the same individual were removed (Altmann 1974). Analyses were restricted to the temporal organization of behaviour during foraging, successions of feeding bouts and interruptions, where birds were standing or swimming in an upright position (head-up vigilance bouts, hereafter scans). We considered foraging to be terminated by any activity other than feeding or scanning (Cézilly \& Brun 1989). Foraging methods were classified into five categories: feeding by diving (the whole body was in the water), feeding by bill (only bill was in the water), feeding by bill and head, (bill and head were in the water), feeding by neck and head (diving with head and neck in the water) and feeding by upending (only tail remains out of water). We collected environmental data during each time block. Air temperature $\left({ }^{\circ} \mathrm{C}\right.$, recorded every $\left.10 \mathrm{mins}\right)$ and wind velocity ( $\mathrm{km} / \mathrm{h}$, recorded continuously). We were unable to conduct systematic nocturnal surveys due to dense vegetation in the control treatments, distances from blinds to study plots, and logistical constraints.

\section{Study site}

Our study area is located in North-eastern Algeria, in the National Park of El-Kala, on the Lake Tonga (in Ramsar since 1983). This lake is ca. 2,500 ha (Belhadj et al. 2007) and it is one of the most significant wetlands of North Africa. Lake Tonga provides important habitats of extensive beds of aquatic plants and nesting sites for several rare and globally threatened waterbirds. It is a significant breeding area for such rare waterfowl as Ferruginous Duck, White-headed Duck (Oxyura leucocephala), Common Pochared (Aythya ferina) and Marbled Teal (Marmaronetta angustirostris). It attracts a rich and varied population of many birds of prey (Smart \& Hollis 1990). The abundant aquatic vegetation of this lake plays a fundamental role in the distribution of waterbirds offering both shelter and food. It is mainly composed by islets of lesser bulrush (Thypha angustifolia), yellow iris (Iris pseudoacorus), lakeshore bulrush (Scripus lacustris), cosmopolitan bulrush (Bolboschoenus maritimus), Australian phragmite (Phragmites australis), Mediterranean willow (Salix pedicellate), and simplestem bur-reed (Sparganium erectum). In spring, we witness the immergence and flowering of very invasive hydrophytes of free-water species, white nenuphar (Nymphaea alba) (Abbaci 1999).

\section{Statistical analyses}

We calculated food intensity of each foraging cycle according to the following formula: IA $=\mathrm{A} /(\mathrm{A}+\mathrm{R})$, where $\mathrm{IA}=$ feeding intensity, $\mathrm{A}=$ duration of feeding phase, and $\mathrm{R}=$ duration of breathing phase (Allouche \& Tamisier 1984, Campredon 1984). We used Pearson's test for correlations, Mann-Whitney's test for comparison between seasons of feeding activities, and packages 'ade4' and 'ade4TkGUI' in the free software R v3.0.3 (R Core Team 2014) for factorial analysis of correspondences (FAC). 


\section{Results}

Results show that the Ferruginous Duck spends the quarter (25.40\%) of the diurnal time with foraging, $30.08 \%$ of the time with swimming, and with comfort activities (preening, resting and sleeping) predominated at a rate of $44.52 \%$. Parade activities and flight recorded only a minimal part of diurnal activity rhythms and thus, have been removed from the analyses.

Diurnal feeding activities indicated two important peaks: the first one in February with a value of $44 \%$, followed by another in April with a value of $59.94 \%$. The lowest values of the diurnal foraging are recorded between the months of June and September, less than $30 \%$ (Figure 1).

The most frequent foraging method observed is feeding by diving ( $46.61 \%$ of food cycle). Other activities, feeding by "bill" by "neck and head" and by "bill and head" are secondary activities and are represented $19.86 \%, 14.53 \%$ and $13.98 \%$, respectively. Up-ending is a minimal activity and represents only $5.99 \%$ of the foraging cycle.

Except feeding by neck and head $(\mathrm{U}=13, \mathrm{n}=12, \mathrm{p}=0.47)$, all other feeding behaviours differ between wintering periods (January-April then November-December) and summer period that spreading between May and October (diving: $U=0, n=12, p<0.01$; toggle: $U$ $=3, \mathrm{n}=12, \mathrm{p}<0.05$; beak: $\mathrm{U}=3, \mathrm{n}=12, \mathrm{p}<0.05$; beak and head: $\mathrm{U}=3, \mathrm{n}=12, \mathrm{p}<0.05$ ) (Figure 2).

FAC demonstrates $78 \%$ of information in axe 1 and 2 . Toggle, neck and head, and beak and head are grouped in positive side of axe 2 while diving (negative side) and beak (positive side) are positioned separately in axe 1 (Figure 3). The first group is associated with April and September, peak with May to August and October. Diving is associated with

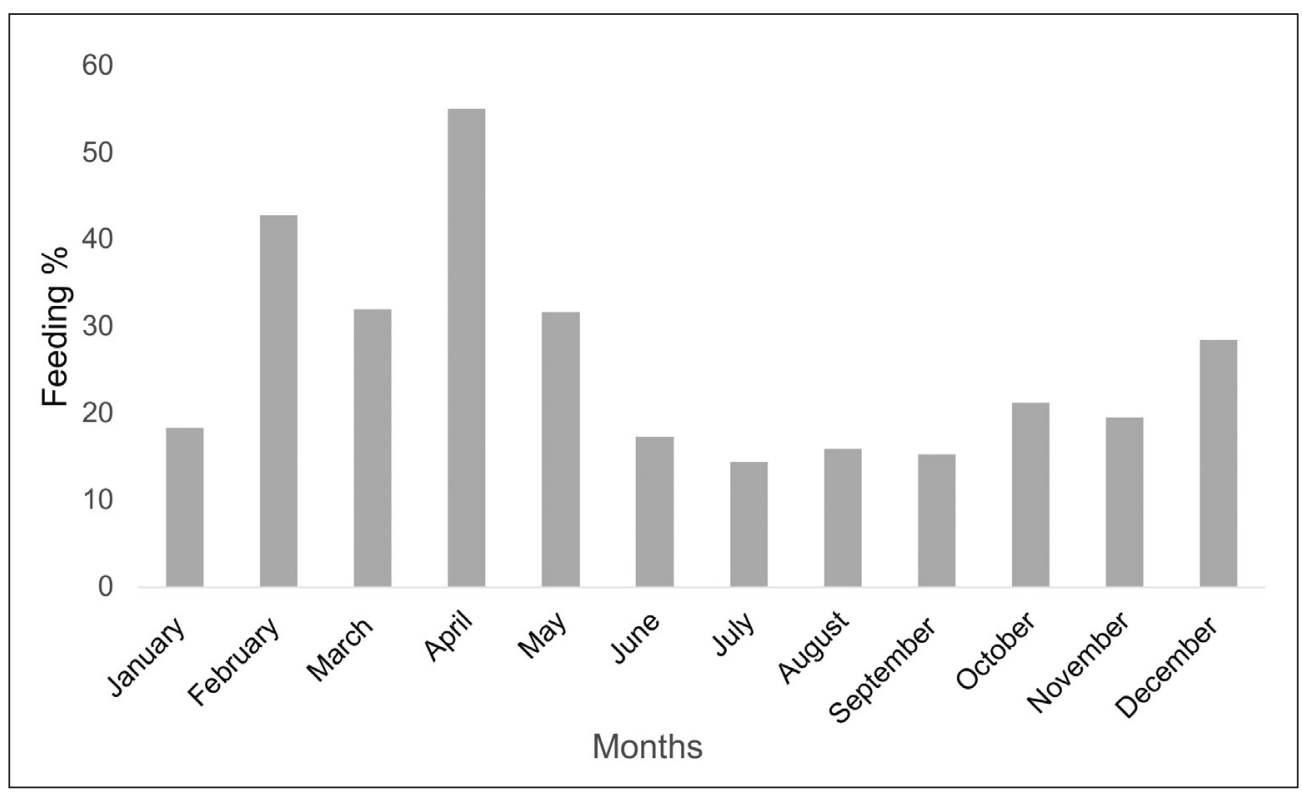

Figure 1. Annual foraging activity of Ferruginous Duck

1. ábra A cigányréce éves táplálkozási aktivitása 


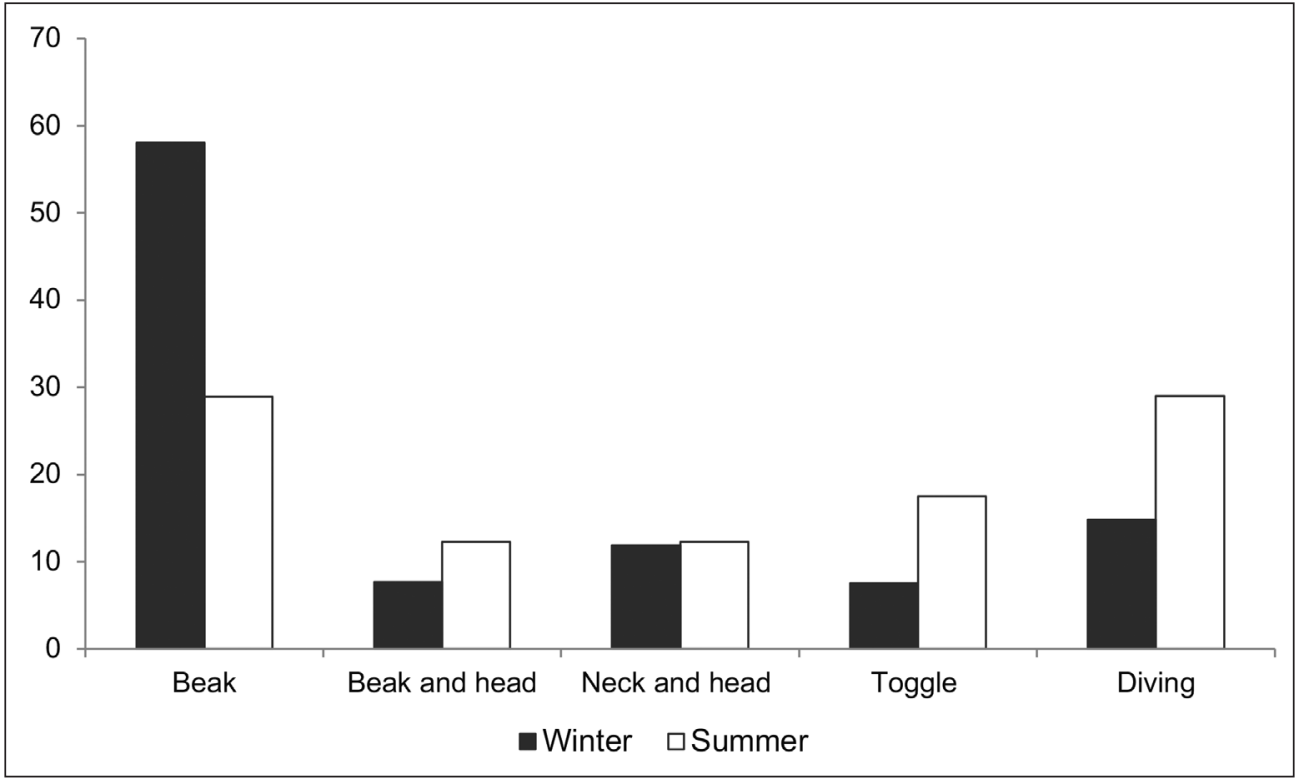

Figure 2. Seasonal differences of foraging activities

2. ábra A táplálkozásmód évszakonkénti változása

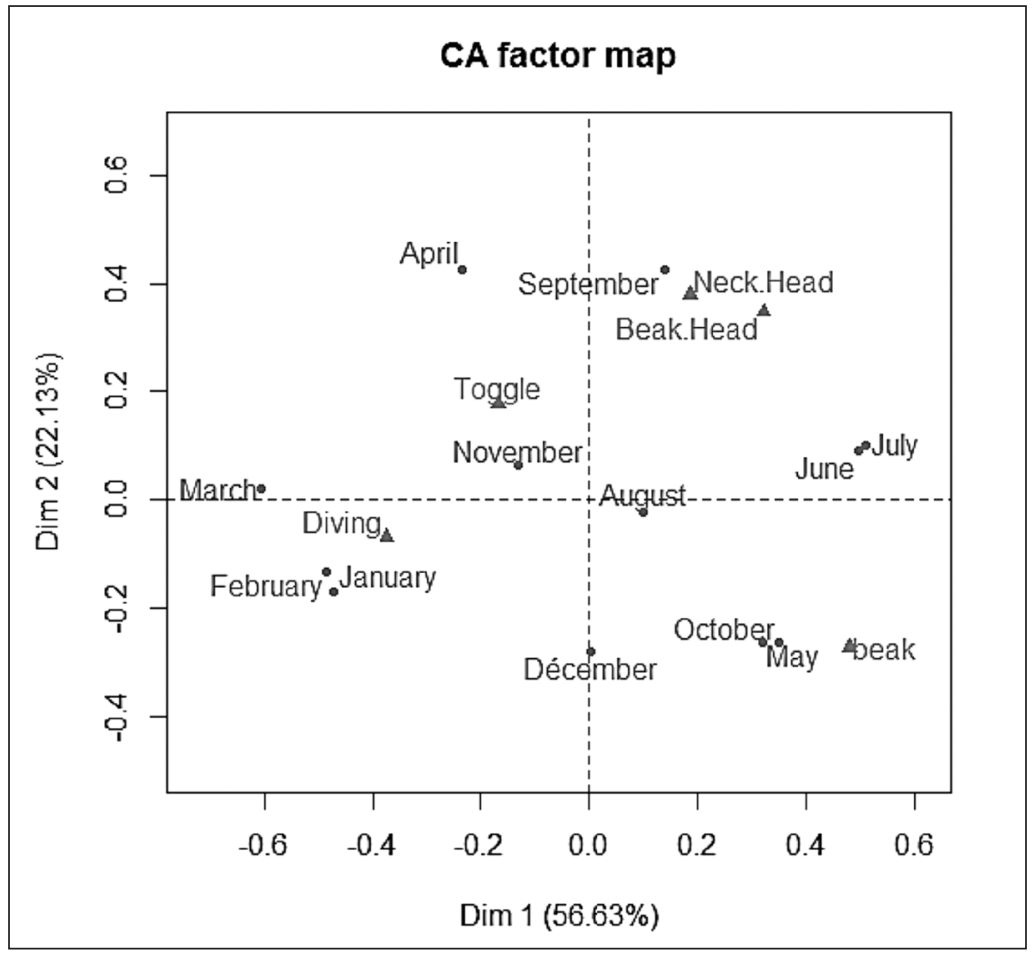

Figure 3. FAC results of foraging activities

3. ábra A táplálkozási aktivitás FAC eredményei 
months from January to March and November.

Feeding intensity is significantly and negatively correlated with the studied factors: rainfall (test of Pearson, $\mathrm{p}<0.002, \mathrm{r}=-$ $0.93)$, temperature $(\mathrm{p}<0.001, \mathrm{r}$ $=-0.74)$, wind speed $(\mathrm{p}<0.001$, $\mathrm{r}=-0.98)$.

Feeding activities linked to the surface are significantly and negatively correlated to the number of ducks on the surface and also to the number of diving ducks. However, foraging activity linked to the depth is significantly and positively correlated to the number of ducks on the surface (Table 1).
Table 1. Correlation between foraging method and bands' sizes

1. táblázat A táplálkozásmód és a csoportméret összefüggései

\begin{tabular}{|c|c|c|}
\hline \multicolumn{1}{|c|}{ Activities } & $\begin{array}{c}\text { number of diving } \\
\text { ducks }\end{array}$ & $\begin{array}{c}\text { number of } \\
\text { surface ducks }\end{array}$ \\
\hline Surface feeding & $r=-0.002$ & $r=-0.096$ \\
& $p=0.99$ & $p=0.019$ \\
\hline \multirow{2}{*}{ Feeding in depth } & $r=0.019$ & $r=0.85$ \\
& $p=0.95$ & $p=0.0004$ \\
\hline
\end{tabular}

Table 2. Feeding intensity by foraging method

2. táblázat A táplálkozás intenzitása az egyes táplálkozásmódok esetében

\begin{tabular}{|l|c|c|c|}
\hline Feeding type & A (in sec.) & R & IA \\
\hline Diving & $16.16 \pm 14.1$ & $15 \pm 12.36$ & $0.56 \pm 0.28$ \\
\hline Up-ending & $3.26 \pm 1.12$ & $3.63 \pm 3.69$ & $0.46 \pm 0.24$ \\
\hline Bill and Head & $5.25 \pm 5.2$ & $4.45 \pm 3.73$ & $0.47 \pm 0.28$ \\
\hline Head and Neck & $9.97 \pm 8.38$ & $9.95 \pm 7.01$ & $0.57 \pm 0.26$ \\
\hline Bill & $0.69 \pm 0.48$ & $1.82 \pm 0.87$ & $0.33 \pm 0.12$ \\
\hline
\end{tabular}

Table 2 shows that diving is the longest foraging behaviour with also a long breathing phase. The shortest behaviour is feeding by bill with a short breathing phase compared to other behaviours. Concerning food intensity, "head and neck" and diving behaviours recorded the highest values.

\section{Discussion}

The results show that the Ferruginous Duck exhibits an important diurnal comfort rate. Our results are supported by other studies. Diurnal resting and other comfort activities in Anatidae represent one of the best ways for rearrangement of energy reserves with a view of migratory for wintering populations (Hill \& Ellis 1984, Rave \& Baldassare 1989, Hohman \& Rave 1990, Green et al. 1999, Tamisier \& Dehorter 1999), as well as, ensure the reproductive success for nesting populations (Hill \& Ellis 1984, Hohman \& Rave 1990, Green et al. 1999). Swimming is an essential activity for ducks, it is often associated with foraging. Individuals of the studied species fatten up by moving. It takes the second place in the total balance of diurnal activities of this species. Prevalence of this activity is basically observed in the beginning of the day and toward the end of the wintering period. Numerous factors determine importance of diurnal foraging. At northern latitudes, birds allocate 80 to $100 \%$ of the diurnal period for feeding (Goss-Custard 1969, 1979), while in more temperate areas, even tropical, this rate is lower, for instance, ranged between 25 and $87 \%$ in Africa (Puttick 1984, Fasola \& Biddau 1997). This is notably explained by upper energy needs for colder temperature. According to Campredon (1984), granivorous or omnivorous ducks devote $35 \%$ of their feeding diurnal time while diving ducks of the genus Aythya generally spend 
less than $30 \%$ of their diurnal time with feeding (Nilsson 1970). For example, this proportion is 23\% for the Ferruginous Duck in Bulgaria (Petkov 2003), 21\% for Tufted Duck (Aythya fuligula) in Switzerland (Pedroli 1982), and 17\% for the Common Pochard (Aythya ferina) (Sabir 2004).

Many ducks, including the Ferruginous, are known to exhibit feeding peak early in the morning and late in the evening (Rodway 1998, Aissaoui et al. 2011). Ferruginous Ducks prefer to forage at night and continue feeding diurnally. The diurnal feeding maxima at the beginning and the end of the day is probably the continuation of the night feeding activity that compensates increase of energy needs spent in thermoregulation. One of the most significant decrease in diurnal foraging, recorded in this study, was observed during nesting period. One of the reasons that may explain this pattern, is the continuous monitoring of chicks against predators - mainly the Western Marsh Harrier (Circus aeruginosus), requiring a continuous presence of adults close to their nests. This decrease could also be a result of increasing temperatures during the day. In fact, the heat stress is a key factor that influences ducks' health and which enhances during hot seasons and in hot regions (Zhu et al. 2014). We believe that the daily heat during summer period forces ducks to decrease their diurnal feeding activity. This loss of time will be compensated by an intensive foraging rate by the end of the day or during the night with temperature decrease This kind of bimodal declining and fluctuating activity pattern, driven by food availability, temperature or the presence of predators, was also recorded by other authors, such as Tanmay (2014), who studied diurnal feeding behaviour of the Ferruginous Duck in Turkey (see also Rodway 1998, Aissaoui et al. 2011).

During winter, we observed that individuals search food more actively by decreasing their moves and their vigilance, essentially during cold days. Poor environmental conditions in this period, combined with the increased number of competitors arriving for winter are force this species to spend more time foraging to maintain thermoregulation/energy supplies. Feeding rate increases also before reproduction period translating the need to accumulate more fat as well as other nutrients essential to female's breeding.

Food resources are generally distributed heterogeneously, both in time and space, and foraging animals show flexible responses to this heterogeneity. This flexibility is expressed at different levels: animals can occupy a new habitat, select a different patch within the same habitat, and select different items within a patch (reviews in Stephens \& Krebs 1986, Hughes 1993, Sutherland 1996). Another kind of behavioral adjustment involves switching search methods (Stephens \& Krebs 1986). Short-term switches or the short-term changes in food searching methods were observed and analysed in numerous animal groups as a rapid and reversible adaptation response to different conditions of food availability (Thomas 1974, Davies 1977, Recher et al. 1983, Formanowicz \& Bradley 1987, Grant \& Noakes 1987, Village 1990, Bell 1991, Nakano et al. 1999). The Ferruginous Duck is an excellent diver, but we have also highlighted other feeding methods less frequent than diving, but have crucial importance in the subventions of nutritional needs. For the Ferruginous Duck, diving remains the most efficient feeding technique because by this method it gathers the most rentable preys in term of energy, which are generally animal materials (benthic macro-invertebrates) (Phillips 1923, Dementiev \& Gladkov 1952, Sterbetz 1969, Cramp \& Simmons 1977, Amat \& Soriguer 1982) or certain plants such as sago pondweed (Potamogeton 
peetinatus), small pondweed (P. panormitanus), and bulrush (Schoenoplectus litoralis), abundant in the benthos. Alternative feeding techniques are dominated by the usage of bill. This technique occurs essentially in shallow waters where vegetation is available at water surface. We believe that this technique also allows ducks to maintain a certain level of vigilance while foraging. This capacity in combination between vigilance and food seeking might be a crucial importance for species whose type and/or energy needs necessitate daily, long foraging. Effectively, individuals may be unable to compensate the loss of the feeding time if vigilance is reached only by "head up", in a time period where feeding is impossible (Martin \& Katzir 1999). Feeding by bill and so other feeding behaviour linked to the surface are generally used to collect insects such as chironomids or submerged seeds (Cramp \& Simmons 1977).

According to Poysa (1983), two reasons may explain the choice of ducks' feeding method; 1) water depth; 2) distribution of prey. In winter, diving ducks are mostly feeding on benthic macro-invertebrates (Nilsson 1972, Stott \& Olson 1973, Bellrose 1980, Jones \& Drobney 1986, Poulton et al. 2002). This kind of prey with high energy can only be obtained by "diving". Depletion of surface resources, presence of great number of several wintering duck species also force the studied species to look for food in the depth. Increase in the rate of foraging activities linked to the surface in summer time may be explained by the abundance of sufficient food resources on the surface to supply energy needs, and also by the need to maintain more vigilance due to presence of chicks during this period (see previous section).

Numerous authors linked foraging behaviour to environmental factors. For instance, Paulus (1984) has studied the Gadwall (Mareca strepera) in Louisiana in October 1977 and in April 1978, and found a negative relationship between ducks' feeding rate and temperature fluctuation. Gaston and Nasci (1989) report that temperature decrease provokes an increase of food seeking. Thompson et al. (1991) found negative correlations between wind speed and foraging rate of four duck species: Blue-winged Teal (Anas discors), Northern Shoveler (A. clypeata), Northern Pintail (A. acuta), and the American Wigeon (A. americana). Results of the present study show a clear decrease in foraging during rainy days. We assumed that ducks have difficulties to reach submerged vegetation because of the increase of water depth, but also of their incapability to locate surface preys due to water turbulence by rains. Our study also shows the negative influence of wind speed on feeding activity. Thompson et al. (1991) emphasizes that wind speed would have more influence on duck's foraging than may have any other climatic parameters. In fact, we noticed that formation of waves on water surface disturbs feeding activity and sometimes completely interrupts it, since wind also disturbs the movements of insects (such as chironomids), which generally depend on the surface vegetation. Furthermore, the influence of temperature, especially thermal stress in hottest or coldest periods, forces ducks to limit their feeding and increase comfort behaviour in order to reduce energy use.

At Lake Tonga, the Ferruginous Duck cohabits with several bird species, especially the Common Pochard, the Northern Shoveler, the Eurasian Teal (Anas crecca), and the Eurasian Coot (Fulica atra). Various studies on habitat use by community of ducks showed separation of niches between species in horizontal dimensions, such as size of wetlands, vegetation characteristics, and chemical characteristics of water (Bengston 1971, Weller 1975, Toft 
et al. 1982, Anderson \& Ohmart 1988, Monda \& Ratti 1988, Bergan \& Smith 1989, Nummi \& Poysa 1993, Nudds et al. 1994). Ferruginous Duck is belonging to the omnivore diving ducks according to diet composition and feeding methods (Pecsics et al. 2017). Some studies demonstrate the presence of vertical partitioning in foraging methods in the depths of water column. Amat (1984) suggested that the Red-crested Pochard (Netta rufina) and the Common Pochard use different habitats with the same foraging strategy in winter, however, they share the same habitat but use different feeding methods in spring. In the present case, results demonstrated clearly that feeding behaviour of Ferruginous Ducks is highly modulated by presence of competitors. In order to optimize its food supply, this species adopts different food-seeking strategies to be able to face the competitiveness. When group size of surface ducks become a constraint, either for consumption intensity of the surface preys or because of prey's disturbance which generate an increase foraging time, it forces this species to dive as the most efficient strategy. Competitiveness with other diving ducks obliges certain individuals to choose surface feeding as a mean to face this constraint. We also noticed interferences between ducks on the same supply spot, which can be manifested in aggressive behaviour of dominant ducks, forcing some individuals to change the foraging site.

Behaviour linked to surface foraging are the shortest in terms of time; this may be explained by the fact that these postures put ducks in position of weakness facing predators, while having eyes under water and the rest of the body exposed. Shortening or fragmenting those phases of foraging seems to be a way to face this constraint. Kramer (1988) discussed that the optimal diving duration are relatively short. Deep, long dives, therefore, will be feasible only with a large reserve in $\mathrm{O}_{2}$. For this, regeneration time would allow fulfilling reserves in $\mathrm{O}_{2}$, which corroborates our results where breathing phases are the longest after diving. During these resting phases, ducks also recover from body heat loss of diving (de Leeuw et al. 1998). As it has already been discussed in the previous chapter; diving is a very efficient foraging method during wintering season, diminution of resources (scarce and change of prays distribution) may explain in part the long dives.

\section{Future perspectives}

Unfortunately, data collected in this study are too limited to explain variation of ducks' feeding behaviour in response to the differences in sex and age of individuals but also in response to productivity fluctuation of the study sites. Study of diet of this species and its eventual seasonal variation, different kinds of disturbance (e.g. predators, human presence) can also help the understanding of certain aspects of the foraging behaviour, where more detailed studies of this species at Lake Tonga, and in other sites of its nesting area in Algeria are needed.

\section{Acknowledgements}

We are most grateful to Cristophe A. H. Bousquet for helpful comments on an earlier draft of this paper. We would like to thank Jenő Nagy and Awatef Abiadh for having kindly improved our text. 


\section{References}

Abbaci, H. 1999. Ecologie du lac Tonga: cartographie de la végétation, palynothèque et l'utilisation de l'espace lacustre par l'avifaune [Tonga Lake Ecology: Vegetation Mapping, Palynothecus and Spatiotemporal Use of Lake Space by waterfowl]. - Mémoire de magistère, University of Annaba, Algeria (in French with English Summary)

Adair, S. E., Moore, J. L. \& Kiel, W. H. 1996. Wintering diving duck use of coastal ponds: an analysis of alternative hypotheses. - Journal of Wildlife Management 60: 83-93. DOI: 10.2307/3802043

Aissaoui, R., Tahar, A., Saheb, M., Guergueb, L. \& Houhamdi, M. 2011. Diurnal behaviour of Ferruginous Duck Aythya nyroca wintering at the El-Kala wetlands (Northeast Algeria). - Bulletin de l'Institut Scientifique, Rabat (section Sciences de la Vie) 33(2): 67-75.

Ali, S. \& Ripley, S. D. 1978. Handbook of the birds of India and Pakistan: together with those of Bangladesh, Nepal, Bhutan and Sri Lanka, Vol. 1., Divers and Hawks, $2^{\text {nd }}$ ed. - Delhi: Oxford University Press, USA

Allouche, L. \& Tamisier, A. 1984. Feeding convergence of Gadwall, American Coot and the other herbivorous waterfowl species wintering in the Camargue: A preliminary approach. - Wildfowl 35: 135-142.

Altmann, J. 1974. Observational study of behaviour: Sampling methods. - Behaviour 49: 227-267. DOI: 10.1163/156853974X00534

Amat, J. A. \& Soriguer, R. C. 1982. Datos sobre selección de habitat y ecología alimenticia del Porrón Pardo (Aythya nyroca) [Data on the habitat selection and feeding habits of the Ferruginous Duck (Aythya nyroca)]. Doñana Acta Vertebrata 9: 388-394. (in Spanish with English Summary)

Amat, J. A. 1984. Ecological segregation between Red-crested Pochard Netta rufina and Pochard Aythya ferina in a fluctuating environment. - Ardea 72: 229-233.

Anderson, B. H. \& Ohmart, R. D. 1988. Structure of the winter duck community on the lower Colorado River: patterns and processes. - In: Weller, M. W. (ed.) Waterfowl in winter. - University of Minnesota Press, Minneapolis, pp. 191-236.

Ankney, C. D. \& MacInnes, C. D. 1978. Nutrient reserves and reproductive performances of female Lesser Snow Geese. - The Auk 95: 459-471.

Ayaichia, F., Samraoui, F., Baaziz, N., Meziane, N. \& Samraoui, B. 2017. Sitting ducks: diet of wintering wildfowl in lake Tonga, northeast Algeria. - Wetlands Ecology and Management 26(2): 231-243. DOI: 10.1007/ s11273-017-9567-6

Bautista, L. M., Tinbergen, J., Wiersma, P. \& Kacelnik, A. 1998. Optimal foraging and beyond: how Starlings cope with changes in food availability. - American Naturalist 152: 543-561. DOI: 10.1086/286189

Belhadj, G., Chalabi, B., Chabi, Y., Kayser, Y. \& Gauthier-Clerc, M. 2007. Le retour de 1'Ibis falcinelle (Plegadis falcinellus) nicheur en Algérie [Return of nesting Glossy Ibis (Plegadis falcinellus) in Algery]. - Aves 44(1): 29-36. (in French with English Summary)

Bell, W. J. 1991. Searching behaviour. The behavioural ecology of finding resources. - Chapman \& Hall, London

Bellrose, F. C. 1980. Ducks, geese and swans of North America, $3^{\text {rd }}$ ed. - Stackpole Books, Harrisburg, Penn

Bengston, S. A. 1971. Hunting methods and choice of prey of Gyrfalcons, Falco rusticolus, at Myvatn in Iceland. - Ibis 113: 468-476. DOI: 10.1111/j.1474-919X.1971.tb05180.x

Bergan, J. P. \& Smith, L. M. 1989. Differential habitat use by diving ducks wintering in South Carolina. - Journal of Wildlife Management 53: 1117-1126. DOI: 10.2307/3809618

Callaghan, D. A. (ed.) 1997. European Species Action Plan: Ferruginous Duck (Aythya nyroca). - The Wildfowl and Wetlands Trust, London

Campbell, L. H. 1978. Diurnal and tidal behaviour patterns of eiders wintering at Leith. - Wildfowl 29: $147-152$.

Campredon, P. 1984. Comportement alimentaire du Canard siffleur (Anas penelope L.) en période hivernale [Feeding behavior of the Eurasian Wigeon (Anas penelope L.) in winter]. - Gibier Faune Sauvage 3: 5-19. (in French)

Cézilly, F. \& Brun, B. 1989. Surveillance et picorage chez la Tourterelle rieuse, Streptopelia risoria: effets de la presence d'un congenere et de la dispersion des grains [Surveillance and cherrying in Laughing Dove Streptopelia risoria: effects of congener presence and seed dispersal]. - Behavior 110: 146-160. DOI: 10.1163/156853989X00448 (in French with English Summary)

Cramp, S. \& Simmons, K. E. L. 1977. The birds of the western Palearctic, Vol. 1. - Oxford University Press, Oxford

Davies, N. B. 1977. Prey selection and the search strategy of the Spotted Flycatcher (Muscicapa striata): a field study on optimal foraging. - Animal Behaviour 25: 1016-1033. DOI: 10.1016/0003-3472(77)90053-7 
de Leeuw, J. J., Butler, P. J., Woakes, A. J. \& Zegwaard, F. 1998. Body cooling and its energetic implications for feeding and diving of Tufted Ducks. - Physiological Zoology 71: 720-730. DOI: 10.1086/516003

Dementiev, G. P. \& Gladkov, N. A. 1952. Birds of the Soviet Union, Vol. 4. - Sovetskaya Nauka, Moscow

Drobney, R. D. 1982. Body weight and composition changes and adaptations for breeding in Wood Ducks. - The Condor 84: 300-305. DOI: $10.2307 / 1367372$

Fasola, M., Biddau, L. 1997. An assemblage of wintering waders in coastal Kenya: activity budget and habitat use. - African Journal of Ecology 35: 339-350. DOI: 10.1111/j.1365-2028.1997.087-89087.

Formanowicz, D. R. \& Bradley, P. J. 1987. Fluctuations in prey density: effects on the foraging tactics of scolopendrid centipedes. - Animal Behavior 35: 453-461. DOI: 10.1016/S0003-3472(87)80270-1

François, J. 1975. L'avifaune annuelle du lac de Boughzoul (Algèrie) [Year-round birds of lake Boughzoul (Algeria)]. - Alauda 43(2): 125-133. (in French)

Gaston, G. R. \& Nasci, J. C. 1989. Diurnal time-activity budgets of nonbreeding Gadwalls (Anas strepera) in Louisiana. - The Proceedings of the Louisiana Academy of Sciences 52: 43-54.

Goss-Custard, J. D. 1969. The winter-feeding ecology of the Redshank Tringa totanus. - Ibis 11(1): 338-355. DOI: 10.1111/j.1474-919X.1969.tb02549.x

Goss-Custard, J. D. 1979. Predicting the effect of loss of feeding grounds on wading birds. - In: Knights, J. B. \& Phillips, A. J. (eds.) Estuarine and Coastal Land Reclamation and Water Storage. - Farnborough: Saxon House, pp. 195-205.

Grant, J. W. A. \& Noakes, D. L. G. 1987. Movers and stayers: foraging tactics of young-of-the-year Brook Charr, Salvelinus fontinalis (Pisces, Salmonidae). - Journal of Animal Ecology 56: 1001-1013. DOI: 10.2307/4962

Green, A. J. 1998. Habitat selection by the Marbled Teal Marmaronetta angustirostris, Ferruginous Duck Aythya nyroca and other ducks in the Gtiksu Delta, Turkey in summer. - Terre et Vie 53: 225-243.

Green, A. J., Fox, A. D., Hughes, B. \& Hilton, G. M. 1999. Time-activity budgets and site selection of White-headed Ducks Oxyura leucocephala at Burdur Lake, Turkey in late winter. - Bird Study 46: 62-73. DOI: $10.1080 / 00063659909461115$

Grimmett, R., Inskipp, C. \& Inskipp, T. 1999. A guide to the birds of the Indian subcontinent. - Princeton University Press, New Jersey

Guillemain, M. \& Fritz, H. 2002. Temporal variation in feeding tactics: exploring the role of competition and predators in wintering dabbling ducks. - Wildlife Biology 8: 81-90. DOI: 10.2981/wlb.2002.012

Guillemain, M., Fritz, H. \& Guillon, N. 2000. Foraging behavior and habitat choice of wintering Northern Shoveler in a major wintering quarter in France. - Waterbirds 23: 355-363. DOI: 10.2307/1522173

Guillemain, M., Martin, G. \& Fritz, H. 2002. Feeding methods, visual fields and vigilance in dabbling ducks (Anatidae). - Functional Ecology 16: 522-530. DOI: 10.1046/j.1365-2435.2002.00652.x

Heitmeyer, M. E. 1988. Body composition of female Mallards in winter in relation to annual cycle. - The Condor 90(3): 669-680. DOI: 10.2307/1368357

Hepworth, G. \& Hamilton, A. 2001. Scan sampling and waterfowl activity budget studies: design and analysis considerations. - Behaviour 138: 1391-1405. DOI: 10.1163/156853901317367654

Hill, D. A. \& Ellis, N. 1984. Survival and age-related changes in the foraging behaviour and time budget of Tufted Ducklings Aythya fuligula. - Ibis 126(4): 544-550. DOI: 10.1111/j.1474-919X.1984.tb02079.x

Hohman, W. L. \& Rave, D. P. 1990. Diurnal time-activity budgets of wintering Canvasbacks in Louisiana. - The Wilson Bulletin 102(4): 645-654.

Hughes, A. J. 1993. Breeding density and habitat preference of the Burrowing Owl in northeastern Colorado. MSc Thesis, Colorado State University, Fort Collins

IUCN 2015. Red list of Threatened Species. - Downloaded from www.redlist.org.

Jones, J. J. \& Drobney, R. D. 1986. Winter feeding ecology of Scaup and Common Goldeneye in Michigan. Journal of Wildlife Management 50: 446-452. DOI: 10.2307/3801102

Kashkarov, D. \& Mukhina, E. 1997. Status of the Ferruginous Duck in Uzbekistan. - TWSG News 10: 21-24.

Kramer, D. L. 1988. The behavioral ecology of air breathing by aquatic animals. - Revue Canadienne de Zoologie 66: 89-94. DOI: 10.1139/z88-012\#.W5mcX84zaM8

Krapu, G. L. 1981. The role of nutrient reserves in Mallard reproduction. - The Auk 98: 29-38.

Landys, M. M., Ramenofsky, M., Guglielmo, G. C. \& Wingfield, J. C. 2004. The low-affinity glucocorticoid receptor regulates feeding and lipid breakdown in the migratory Gambel's White-crowned Sparrow Zonotrichia leucophrys gambelii. - Journal of Experimental Biology 207: 143-154. DOI: 10.1242/jeb.00734

Lopez, A. \& Mundkur, T. 1997. The Asian waterfowl census, 1994-1996. Results of the coordinated waterbird census and an overview of the status of wetlands in Asia. - Wetlands International, Kuala Lumpur 
Martin, G. R. \& Katzir, G. 1999. Visual field in Short-toed Eagles Circaetus gallicus and the function of binocularity in birds. - Behavior and Evolution 53: 55-66. DOI: 10.1159/000006582

Monda, M. J. \& Ratti, J. T. 1988. Niche overlap and habitat use by sympatric duck broods in eastern Washington. - Journal of Wildlife Management 52: 95-103. DOI: 10.2307/3801066

Nakano, S., Miyasaka, H. \& Kuhara, N. 1999. Terrestrial-aquatic linkages: riparian arthropod inputs alter trophic cascades in a stream food web. - Ecology 80: 2435-2441. DOI: 10.2307/176923

Nilsson, L. 1970. Food seeking activity of south Swedish diving ducks in the non-breeding season. - Oikos 21: 145-15. DOI: $10.2307 / 3543670$

Nilsson, L. 1972. Local distribution, food choice and food consumption of diving ducks on a south Swedish lake. - Oikos 23: 82-91. DOI: 10.2307/3543929

Norman, F. I., Thomson, L. W. \& Hamilton, J. G. 1979. Use of habitat and diurnal activity of Pacific Black Duck, Chestnut Teal and Grey Teal at Serendip Victoria. - Emu 79: 54-62. DOI: 10.1071/MU9790054

Nudds, T. D., Sjoberg, K. \& Lundberg, P. 1994. Ecomorphological relationships between Palearctic dabbling ducks on Baltic coastal wetlands and a comparison with the Nearctic. - Oikos 69: 295-303. DOI: 10.2307/3546150

Nummi, P. \& Poysa, H. 1993. Habitat associations of ducks during phases of the breeding season. - Ecography 16: 319-328. DOI: 10.1111/j.1600-0587.1993.tb00221.x

O’Donoghue, P. D. \& O'Halloran, J. 1994. The behaviour of a wintering flock of Whooper Swans Cygnus cygnus at Rostellan Lake, Cork. - Biology and Environment: Proceedings of the Royal Irish Academy 94B (2): $109-118$.

Owen, M. \& Black, J. M. (eds.) 1990. Waterfowl Ecology Glasgow and London. - Tertiary Level Biology, Blackie

Paspaleva, M., Kiss, J. B. \& Talpeanu, M. 1984. On the dynamics of some dominant bird species in the Danube Delta. - Travaux du Muséum d'Histoire Naturelle "Grigore Antipa" 25: 312-329.

Patrikeev, M. 1996. The status of the Ferruginous Duck in Azerbaijan. - Threatened Waterfowl Specialist Group News 9: 30-32.

Pattenden, R. K. \& Boag, D. A. 1989. Effects of body mass on courtship, pairing and reproduction in captive Mallards. - Revue Canadienne de Zoologie 67: 495-501. DOI: 10.1139/z89-072

Paulus, S. L. 1984. Activity budgets of nonbreeding Gadwalls in Louisiana. - The Journal of Wildlife Management 42: 371-380. DOI: $10.2307 / 3801168$

Pecsics, T., Laczi, M., Nagy, G. \& Csörgő, T. 2017. The cranial morphometrics of the wildfowl (Anatidae). - Ornis Hungarica 25(1): 44-57. DOI: 10.1515/orhu-2017-0004

Pedroli, J. C. 1982. Activity and time budgets in Tufted Ducks on Swiss lakes during winter. - Wildfowl 33: $105-112$.

Perennou, C., Mundkur, T. \& Scott, D. 1994. The Asian Waterfowl Census 1987-91: distribution and status of Asian waterfowl. - University of Malaya and International Waterfowl and Wetlands Research Bureau

Petkov, N. 2003. Ferruginous Duck habitat characteristics and diurnal activity rhythm in Bulgaria. - In: Petkov, N., Hughes, B. \& Gallo-Orsi, U. (eds.) Ferruginous Duck: from research to conservation. - Conservation Series No. 6. Sofia: Birdlife International, RSPB and TWSG.

Phillips, J. C. 1923. A natural history of the ducks, Vol. 2. - Houghton-Mifflin Co., Boston and New York

Poulton, V. K., Lovvorn, J. R. \& Takekawa, J. Y. 2002. Clam density and Scaup feeding behavior in San Pablo Bay, California. - Condor 104: 518-527. DOI: 10.1650/0010-5422(2002)104[0518:CDASFB]2.0.CO;2

Poysa, H. 1983. Morphology-mediated niche organization in a guild of dabbling ducks. - Ornis Scandinavica 14: 317-326. DOI: $10.2307 / 3676325$

Puttick, G. M. 1984. Foraging and activity patterns of wintering shorebirds. - In: Burger, J. \& Olla, B. L. (eds.) Shorebirds: migration and foraging behavior. - Plenum Press, New York, pp. 203-231.

Pyke, G. H. 1984. Optimal foraging: a critical review. - Annual Review of Ecology and Systematics 15: 523-575. DOI: 10.1146/annurev.es.15.110184.002515

Rave, D. P. \& Baldassarre, G. A. 1989. Activity budgets of Green-winged Teal wintering in wetlands of Louisiana. - Journal of Wildlife Management 53: 753-759. DOI: 10.2307/3809208

Recher, H. F., Gowing, G., Kavanagh, R., Shields, J. \& Rohan-Jones, W. 1983. Birds, resources and time in a tablelands forest. - The Ecological Society of Australia 12: 101-123.

Robinson, J. A. \& Hughes, B. 2003. The global status and distribution of the Ferruginous Duck. Ferruginous Duck: from research to conservation. Sofia. - Birdlife International, pp. 8-17.

Rodway, M. S. 1998. Activity patterns, diet and feeding efficiency of Harlequin Ducks breeding in northern Labrador. - Revue Canadienne de Zoologie 76: 902-909. DOI: 10.1139/z98-019 
Sabir, B. M. 2004. Diurnal time-activity budgets in wintering Ferruginous Pochard Aythya nyroca in Tanguar Haor, Bangladesh. - Forktail 20: 25-27.

Skead, D. M. 1977. Interspecific and aggressive behavior of Anatini. - Ostrich (Suppl.12): 133-134.

Smart, M. \& Hollis, G. E. 1990. Ramsar convention monitoring procedure. - Report no. 22 [now numbered as 21] Lac Oubeira and Lac Tonga, Algeria

Stephens, D. W. \& Krebs, J. R. 1986. Foraging Theory. - Princeton University Press, Princeton, New Jersey

Sterbetz, I. 1967. Economic and nature-conservation problems in feeding habits of Hungarian Mallard. - Aquila 73-74: 133-145.

Sterbetz, I. 1969. Feeding ecology of the Ferruginous Duck in Hungary. - Unpublished Report, Hungarian Ornithological Institute, Budapest

Stott, R. S. \& Olson, D. P. 1973. Food-habitat relationships of sea ducks on the New Hampshire coastline. - Ecology 54: 996-1007. DOI: 10.2307/1935566

Sutherland, W. J. 1996. From individual behavior to population ecology. - Oxford University Press, Oxford

Tamisier, A. \& Dehorter, O. 1999. Camargue, canards et foulques: fonctionnement et devenir d'un prestigieux quartier d'hiver [Camargue, Ducks and Eurasian Coot: Functionning and becoming of winter quarter]. - National Museum of Natural History, Centre Ornithologique du Gard Nîmes, France, Vol. 1., p. 369. (in French)

Tanmay, D. 2014. Time-activity budgets of wintering Ferruginous Duck, Aythya nyroca, at Gajoldoba wetland, Jalpaiguri, India. -Turkish Journal of Zoology 38: 538-543. DOI: 10.3906/zoo-1304-39

Thomas, G. 1974. The influence of encountering a food object on the subsequent searching behaviour of Gasterosteus aculeatus L. - Animal Behaviour 22: 941-952. DOI: 10.1016/0003-3472(74)90017-7

Thompson, D., Thompson, P. S., Hammond, K. S., Nicholas, M. A. \& Fedak, M. A. 1991. Movements, diving and foraging behaviour of Grey Seals (Halichoerus grypus). - Journal of Zoology 224 (2): 223-232. DOI: 10.1111/j.1469-7998.1991.tb04801.x

Toft, C. A., Trauger, D. L. \& Murdy, H. W. 1982. Tests for species interactions - Breeding phenology and habitat use in subarctic ducks. - The American Naturalist 120: 586-613. DOI: 10.1086/284015

Village, A. 1990. The Kestrel. - T \& AD Poyser, London

Weller, M. W. 1975. Studies of cattail in relation to management for marsh wildlife. - Iowa State Journal of Research Records 49(4): 383-412.

Zhu, W., Jiang, W. \& Wu, L. Y. 2014. Dietary L-arginine supplement alleviates hepatic heat stress and improves feed conversion ratio of Pekin ducks exposed to high environmental temperature. - Journal of Animal Physiology and Animal Nutrition 98(6): 1124-1131. DOI: 10.1111/jpn.12195

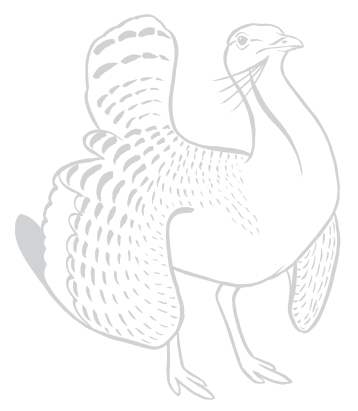

